\title{
Evaluation of Hyponatremia As A Single Best Parameter Predicting Prognosis And Monitoring Tool In Patients With Sepsis
}

\author{
Dr.S.Muthulakshmi ${ }^{1}$, Dr.M.Muralidharan ${ }^{2}$, Dr.S.Natarajan ${ }^{3}$ \\ ${ }^{I}$ (Assistant professor, Department of General Surgery, Coimbatore Medical College,TN , India) \\ ${ }_{2}^{2}$ (Post Graduate in M.S. General Surgery, Department of General Surgery,Coimbatore Medical College, India) \\ 3(Professor,Department of General Surgery,Coimbatore Medical College,TN,India)
}

\begin{abstract}
:
BACKGROUND : Sepsis has high morbidity and mortality potential. Hence it becomes necessary to have some readily available tool which can be used both to predict the prognosis and also monitor it through out. Critically ill patients are more prone for electrolyte disturbances and especially hyponatremia. Being a readily available biochemical parameter this study is conducted to evaluate the effectiveness of serum sodium levels to predict and monitor the prognosis in sepsis.
\end{abstract}

METHODS : In this prospective study conducted from may-2016 to october-2016 at department of general surgery, coimbatore medical college the patients admitted with features of sepsis based on SIRS criteria were subjected to serum sodium estimation on admission, $2^{\text {nd }}$ day and on 7th day. The results and the recovery from illness were noted and statistically analysed.

RESULTS : On statistical analysis by chi-square test, serum sodium estimation on admission, $2^{\text {nd }}, 7$ th days were showing $p$ value of $<0.001$ to predict mortality.

CONCLUSION : serum sodium estimation can be used as a basic, cheap, reliable and reproducible single parameter to predict prognosis and serial estimation can be used for monitoring the progress.

Keywords: hyponatremia, sepsis, eunatremia, SIRS, mortality.

\section{BACKGROUND}

\section{Introduction}

Sepsis ${ }^{[1]}$ is a systemic inflammatory response syndrome, provoked by a documented or presumed infection. It progresses very rapidly to a more severe stage with multi organ dysfunction ${ }^{[2]}$. This condition has high morbidity and mortality ranging from $16 \%$ to $50 \%$ in septic shock. Hence it becomes necessary to develop a easily available, reproducible, clinical parameter which could predict the prognosis and can also monitor the progress of sepsis. Serum sodium level which is routinely taken as investigation in sepsispatient shows correlation to the severity of sepsis. Hyponatremia is a common electrolyte disturbance occurring in critically ill ${ }^{[3,4]}$ patients. Symptoms range from nausea and malaise, with mild reduction in the serum sodium, to lethargy, decreased level of consciousness, headache, seizures and coma.

Hyponatremia $^{[5]}$ can be classified on the basis of serum osmolality, volume status and urinary sodium into hypertonic, isotonic and hypotonic types. Hypotonic hyponatremia is further classified into hypervolemic, euvolemic and hypovolemic as follows.

- Hypovolemic hyponatremia: Decreased total body sodium and decreased total body water. The sodium deficit exceeding water deficit

- Euvolemic hyponatremia ${ }^{[6,7]}$ : Normal body sodium with increase in total body water

- Hypervolemic hyponatremia ${ }^{[8]}$. Increase in total body sodium with greater increase in total body water.

\section{SUBJECT AND PURPOSE OF THE PROJECT}

To prospectively validate hyponatremia as a single best parameter to predict the prognosis and monitor the progress in patients with sepsis ${ }^{[9]}$.

\section{DATA COLLECTION}

Patients presenting to emergency department, department of surgery, Coimbatore medical college hospital during the period of may-2016 to october-2016 were screened for evidence of systemic inflammatory response syndrome.

For those patients periodic serum sodium level will be taken and analysis will be done later.

\section{OBJECTIVES OF THE STUDY}

To analyse the predictive value of serum sodium in prognosis of sepsis. 
STUDY DESIGN

Prospective cohort study.

METHODOLOGY

SERUM SODIUM LEVELS WERE MEASURED DURING ADMISSION, $2^{\mathrm{ND}}$ DAY AND $7^{\mathrm{TH}}$ DAY.

The patients were divided into two groups:

Hyponatremic (serum sodium $<135 \mathrm{mmol} / \mathrm{L}$ ) and

Eunatremic groups (135-145 mmol/L).

\section{INCLUSION CRITERIA}

- Patients presenting to department of surgery at Coimbatore medical college hospital with features of sepsis.

- Patients with features of SIRS.

SIRS is defined as 2 or more of the following variables

- Fever of more than $38^{\circ} \mathrm{C}\left(100.4^{\circ} \mathrm{F}\right)$ or less than $36^{\circ} \mathrm{C}\left(96.8^{\circ} \mathrm{F}\right)$

- Heart rate of more than 90 beats per minute

- Respiratory rate of more than 20 breaths per minute or arterial carbon dioxide tension $\left(\mathrm{PaCO}_{2}\right)$ of less than $32 \mathrm{~mm} \mathrm{Hg}$

- Abnormal white blood cell count $(>12,000 / \mu \mathrm{L}$ or $<4,000 / \mu \mathrm{L}$ or $>10 \%$ immature [band] forms)

- Aged 18 years and above.

- Between May 2016 to October 2016.

\section{EXCLUSION CRITERIA}

- Patients below 18 years.

- Pregnant patients.

- Patients with hypernatremia.

\section{DATA ANALYSIS}

Totally 72 patients presenting with features of sepsis were included in the study. Serial serum sodium level estimation was done on admission, $2^{\text {nd }}$ and $7^{\text {th }}$ day. 12 patients had sodium values more than $145 \mathrm{mEq} 1 / 1$ and were excluded from the study. Rest of the 60 candidates were screened and mortality was analysed.

Table 1 - Hyponatremia on admission correlating with sepsis mortality.

Chi-Square test on admission reveals 21.98 . hence $\mathrm{p}<0.001$, highly statistically significant and there exsists correlation between mortality in sepsis and hyponatremia.

\begin{tabular}{|c|c|c|c|}
\hline \multirow{2}{*}{$\begin{array}{c}\text { HYPONATREMIA } \\
\text { ON ADMISSION }\end{array}$} & \multicolumn{2}{|c|}{ MORTALITY } & \multirow{2}{*}{ TOTAL } \\
\cline { 2 - 4 } & PRESENT & ABSENT & 34 \\
\hline PRESENT & 26 & 8 & 26 \\
\hline ABSENT & 4 & 22 & 60 \\
\hline TOTAL & 30 & 30 & \\
\hline
\end{tabular}

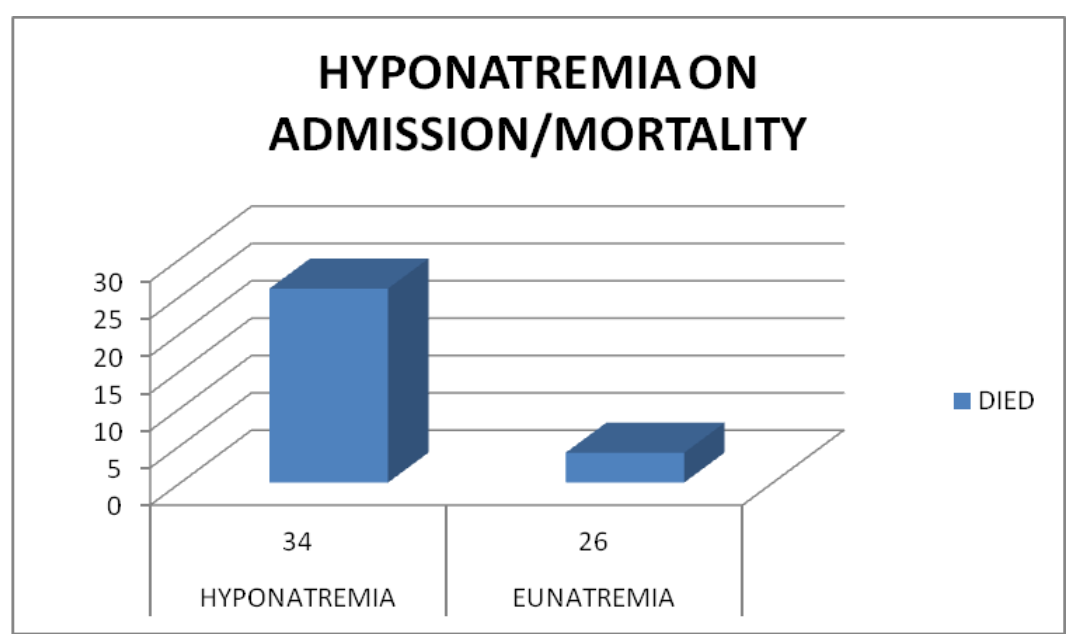

Fig 1 - Hyponatremia on admission correlating with sepsis mortality. 
Table 2 - Hyponatremia on $2^{\text {nd }}$ day correlating with sepsis mortality.

Chi-Square test on $2^{\text {nd }}$ day reveals 32.4 . hence $\mathrm{p}<0.001$, highly statistically significant and there exsists correlation between mortality in sepsis and hyponatremia.

\begin{tabular}{|c|c|c|c|}
\hline \multirow{2}{*}{$\begin{array}{c}\text { HYPONATREMIA } \\
\text { ON } 2^{\text {ND }} \text { DAY }\end{array}$} & PRESENT & MORTALITY & \multirow{2}{*}{ TOTAL } \\
\cline { 2 - 3 } & 27 & 5 & 32 \\
\hline PRESENT & 3 & 25 & 28 \\
\hline ABSENT & 30 & 30 & 60 \\
\hline TOTAL & & & \\
\hline
\end{tabular}

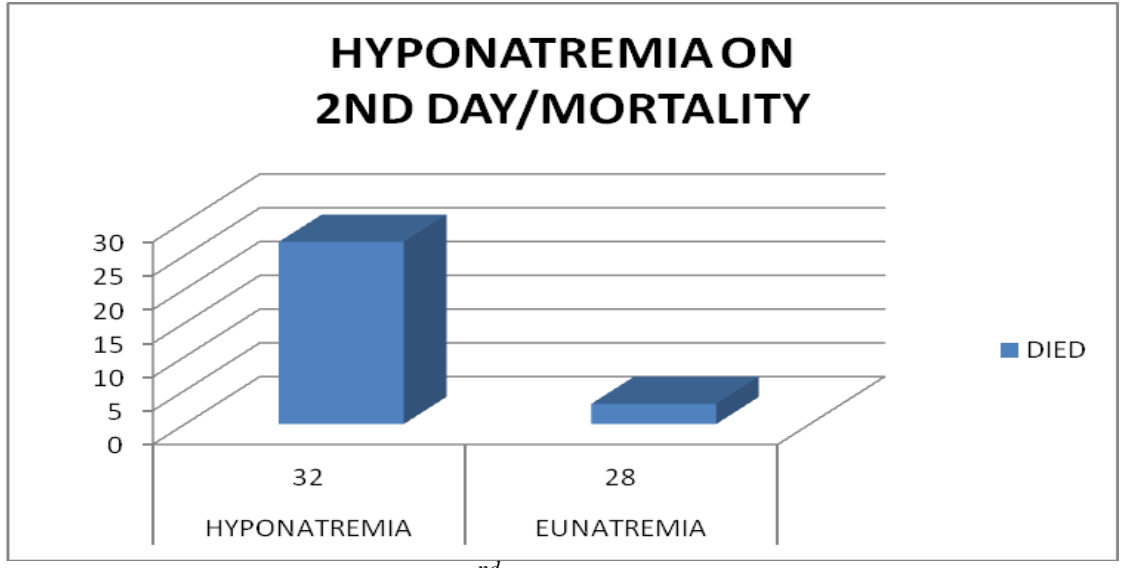

Fig 2 - Hyponatremia on $2^{\text {nd }}$ day correlating with sepsis mortality.

Table 3 - Hyponatremia on $7^{\text {th }}$ day correlating with sepsis mortality.

Chi-Square test on $7^{\text {th }}$ day reveals 45.08 . hence $p<0.001$, highly statistically significant and there exists correlation between mortality in sepsis and hyponatremia.

\begin{tabular}{|c|c|c|c|}
\hline \multirow{2}{*}{$\begin{array}{c}\text { HYPONATREMIA } \\
\text { ON } 7^{\mathrm{TH}} \text { DAY }\end{array}$} & PRESENT & ABSENT & \multirow{2}{*}{ TOTAL } \\
\cline { 2 - 4 } & 28 & 2 & 30 \\
\hline PRESENT & 2 & 28 & 30 \\
\hline ABSENT & 30 & 30 & 60 \\
\hline TOTAL & \multicolumn{2}{c}{} \\
\hline
\end{tabular}

\section{HYPONATREMIAON 7TH DAY/MORTALITY}

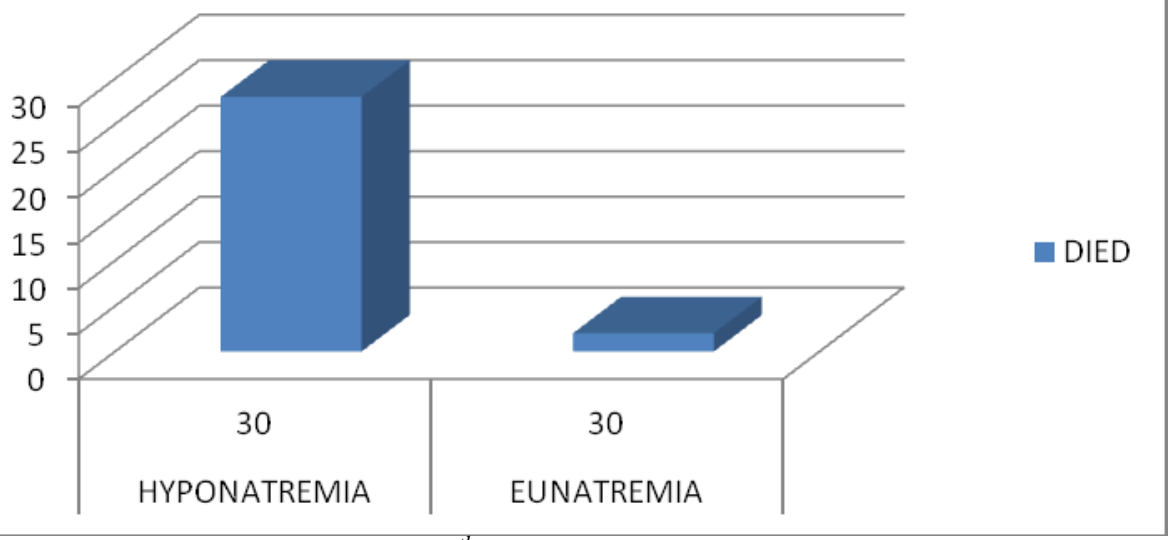

Fig 3 - Hyponatremia on $7^{\text {th }}$ day correlating with sepsis mortality. 
Fig 4-Serum sodium level on admission, $2^{\text {nd }} \& 7^{\text {th }}$ day in study group.

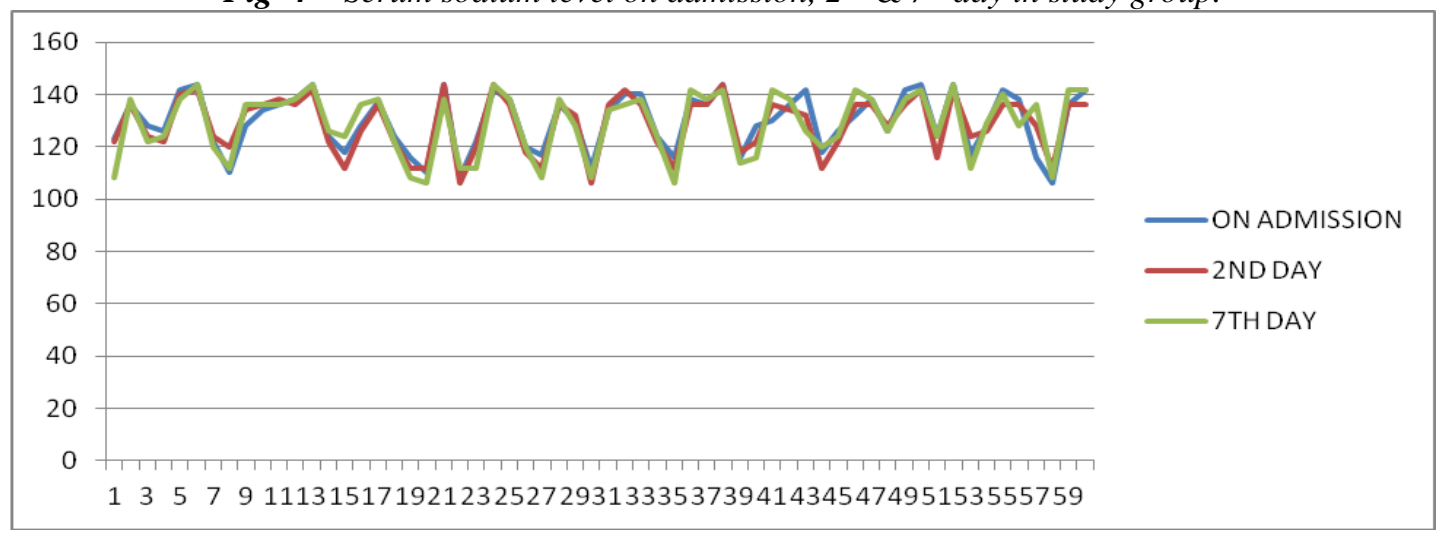

\section{Conclusion}

Serum sodium estimation during the course of sepsis shows highly significant correlation with mortality. Hence serum sodium estimation is a single best reliable, cheap, reproducible parameter predicting prognosis and a monitoring tool in sepsis.

\section{References}

[1]. DeVita MV, Gardenswartz MH, Konecky A, Zabetakis PM. Incidence and etiology of hyponatremia in an intensive care unit. Clin Nephrol. 1990;34:163-6.[PubMed]

[2]. Vincent JL, de Mendonça A, Cantraine F, Moreno R, Takala J, Suter PM, et al. Use of the SOFA score to assess the incidence of organ dysfunction/failure in intensive care units: Results of a multicenter, prospective study. Working group on "sepsis-related problems" of the European Society of Intensive Care Medicine. Crit Care Med. 1998;26:1793-800.[PubMed]

[3]. Bartter FC, Schwartz WB. The syndrome of inappropriate secretion of antidiuretic hormone. Am J Med. 1967;42:790806.[PubMed]

[4]. Bone RC, Balk RA, Cerra FB, Dellinger RP, Fein AM, Knaus WA, et al. Definitions for sepsis and organ failure and guidelines for the use of innovative therapies in sepsis. The ACCP/SCCM Consensus Conference Committee. American College of Chest Physicians/Society of Critical Care Medicine. Chest. 1992;101:1644-55.[PubMed]

[5]. Moritz ML, Ayus JC. Dysnatremias in the critical care setting. Contrib Nephrol. 2004;144:132-57. Ayus JC, Arieff AI. Brain damage and postoperative hyponatremia: The role of gender. Neurology 1996;46:323-8. [PubMed]

[6]. Bennani SL, Abouqal R, Zeggwagh AA, Madani N, Abidi K, Zekraoui A, et al. Incidence, causes and prognostic factors of hyponatremia in intensive care. Rev Med Interne. 2003;24:224-9.[PubMed]

[7]. Berghmans T, Paesmans M, Body JJ. A prospective study on hyponatraemia in medical cancer patients: Epidemiology, aetiology and differential diagnosis. Support Care Cancer. 2000;8:192-7.[PubMed]

[8]. Anderson RJ, Chung HM, Kluge R, Schrier RW. Hyponatremia: a prospective analysis of its epidemiology and the pathogenetic role of vasopressin. Ann Intern Med. 1985 Feb;102(2):164-168.[PubMed]

[9]. Sterns RH, Cappuccio JD, Silver SM, Cohen EP. Neurologic sequelae after treatment of severe hyponatremia: a multicenter perspective. J Am Soc Nephrol. 1994 Feb;4(8):1522-1530.[PubMed] 